\title{
THROMBOPHLEBITIS FOLLOWING THIOPENTONE INJECTION
}

\author{
David Jameson, Ph.C.," Cl,aUde DEsjardins, M.D., \\ AND JEAN CARON, M.D., F.R.C.P.(c) $†$
}

Thrombophlebrrs of the upper limb is an uncommon complication of thiopentone (Pentothal ${ }^{9}$ ) infection. Wylie and Churchill-Davidson ${ }^{1}$ state that venous thrombosis following thiopentone injection has but rarely been reported. Four cases of venous thrombosis in a series of two hundred unselected surgical patients have been reported by Hutton and Hall in 1957, involving as a factor the use of 5 per cent solution. ${ }^{2}$ This present report concerns the occurrence of at least thirty cases of chemical thrombophlebitis at Chalcur Regional Hospital, Bathurst, New Brunswick, during the six-month period from August 1971 to February 1972, following the injection of $2 /$ per cent thiopentone solution.

\section{Clintcat, Description}

Typically the onset of pain, redness and slight swelling came on the fourth postoperative day after the injection of thiopentone for anaesthesia. Inspection of the upper limb showed tender hard veins, beginning at the level of the original injection site and palpable up to the antecubital fossa or higher. In most cases the subcutaneous swelling and redness subsided in a few days, but the tendemess and hardness of the veins persisted for weeks or months.

Many patients who developed this complication were alarmed and sought help from physicians, surgeons or anaesthetists. They were treated conservatively with compresses and local heat. In those cases which lasted several months the patients complained of pain not only in the forearm, but also in the arm, in the neck or in the shoulder of the same side. There was a tendency to experience coldness and numbness of the hand, especially in cold weather.

\section{INVESTIGATION AND Discussion}

The first six cases occurred in a $4 \frac{1}{z}$-month period. Thus they were spaced enough in time not to attract much attention.

It was soon established that nearly all of the female patients affected by the syndrome were not taking oral contraceptives.

It was thought that the disposable syringes and needles then in use might be implicated, and in mid-December the hospital administration was asked that in the operating room these should be replaced by similar supplies from another company. At this time no consideration was given to the possibility that thiopertone might have been implicated. This is probably explained by the old axiom

- Director, Department of Pharmacy, Chaleur Regional Hospital, Bathurst, N.B. †Anaesthetist, Chaleur Regional Hospital, Bathurst, New Brunswick.

659

Canad. Anaesth. Soc. J., vol. 19, no. 6, November 1972 
"Cresar's wife should be above suspicion." Decades of experience with thiopentone have not produced so many cases of thrombophlebitis in so little time.

In February, representaives from the company supplying the disposable needles and syringes to the hospital were able to convince the authors that no contamination or harmful chemical from their injection supplies could be involved. By this time careful bacteriological control of these supplies had revealed no contamination.

Turning our attention to the thiopentone we were using, it was decided to abandon the $1 \mathrm{gm}$ vial of thiopentone and the $50 \mathrm{ml}$ vial of diluent saline solution which we were using and to return to the use of the $5 \mathrm{gm}$ multiple dose bottle with $250 \mathrm{ml}$ diluent bottle which we had previously used until 1970. This decision was taken when the total number of cases of thrombophlebitis had reached the astonishing figure of thirty. No simple case of thrombophlebitis has come to our attention since this change was made.

In early March of 1972 an enquiry was addressed to The Canadian Anaesthetists' Society to determine whether other cases of this complication had come to their attention. Dr. Stuart Vandewater answered this letter and, while informing us that he and the socicty were not aware of other cases in Canada he made suggestions which helped in the elucidation of the probtem. ${ }^{3}$ He pointed out that the $\mathrm{pH}$ (10.5) of the solution would likely preclude the possibility of bacterial contamination.

The company supplying us with thiopentone has since reported that analysis of the suspected solution of the $1 \mathrm{gm}$ in the $50 \mathrm{ml}$ of solution showed that it contained 6 per cent of the thiopentone in the undissolved state. It seemed, therefore, that the explanation for the chemical irritation to the vein was obvious; that these solid particles had adhered to and caused damage to the wall of the vein. The saline diluent supplied to us contained $9 \mathrm{mg}$ per $\mathrm{ml}$ of benzyl alcohol in addition to the usual $9 \mathrm{mg}$ of $\mathrm{NaCl}$.

The failure of 6 per cent of the thiopentone to dissolve has yet to be explained.

\section{RÉSUMÉ}

Les thrombo-phlébites ayant pour cause l'injection intraveineuse du thiopentone sont assez rares ... Nous avons cependant compté trente cas de cette complication à l'Hôpital Régiona! Chaleur de Bathurst, N.-B., durant la période août 1971février 1972.

Les patients affectés présentaient ordinairement un avant-bras sillonné de veines durcies, douloureuses, avec ódème et rougeur en évidence. Souvent la douleur persistait pendant plusieurs mois.

Au début la cause nous parut être les aiguilles ou les seringues que nous employions, et longtemps nous n'avons aucunement soupçonné le thiopentone a 2.5 pour cent, provenant de la fiole de $1 \mathrm{gm}$ et la fiole de diluent salin de $50 \mathrm{ml}$. Toutefois, lorsque cette solution fut enfin échangée contre du thiopentone provenant d'un contenant de $5 \mathrm{gm}$, et mélangé à un soluté salé pris dans une bouteille de $250 \mathrm{ml} \mathrm{le}$ problème fut résolu promptement, et les thrombo-phlêbites disparurent.

La compagnie qui a fait l'analyse de la solution suspecte nous a fait savoir par la suite que 6 pour cent du thiopentone ne s'était pas dissous. Nous croyons que 
des parcelles à l'êtat solide ont adhéré aux parois des veines au cours des injections et ainsi établi les foyers d'inflammation et thrombose en question.

La raison pour laquelle unc quantité de 6 pour cent du thiopentone ne se fut pas dissoute nous échappe.

\section{REFERENCES}

1. Wrute, W.D. \& ChunchILL-Davmson, H.C. A practice of ansesthesia. London, LloydLuke, 2nd Ed. (1966)

2. Hutron, A.M. HALL J.M. Incidence of thrombosis following thiopental. Anaesthesia 12, 467 (1957)

3. VANDEWATEH, S.L. Personal communication. 